\title{
Trestní odpovědnost osob činných ve volených orgánech územních samosprávných celků
}

\section{Criminal Liability of Persons Engaged in Elected Bodies of Local Governments}

\author{
Petr Zarivnij*
}

\begin{abstract}
Abstrakt
Clánek je zamèren na problematiku trestni odpovédnosti osob ve vątabu k jejich členstvi a rozhodování ve volených orgánech územnich samospráuných celkè. V rámci článku je predstavena typická trestná cimnost páchaná v této oblasti a reflektována otázkea, do jaké míry lze osoby činné ve volených orgánech územnich samosprávných celkè trestnè stíhat. Úvahám jsou podrobeny problematické body činnosti samosprávy a doporučeni za účelem prevence trestníbo stíhání.
\end{abstract}

\section{Klíčová slova}

Orgány územnich samosprávných celkị; porušení povinnosti prü správě cizího majetku; trestni odpovédnost; zastupitelé; zneužiti pravomoci úredni osoby.

\section{Abstract}

The article is focused on the issue of criminal liability of persons in relation to their membership and decision making in elected bodies of local governments. In this context are presented typical crimes committed in subject area, as well as the question of the extent to which persons engaged in elected bodies of local governments can be prosecuted. Considered are also selected problematic issues of local government actions and recommendations to prevent criminal prosecution.

\section{Keywords}

Bodies of Local Governments; Breach of Trust; Criminal Liability; Councillors; Abuse of Power by a Public Official.

\section{1 Úvodem}

V posledních letech jsme byli svědky rostoucího zájmu o otázku trestní odpovědnosti osob činných ve volených orgánech územních samosprávných celků. Zejména pak, zda je či není ze strany orgánů činných v trestním řízení zasahováno do ústavně garantovaného práva na samosprávu. Bez komplikovaných obstrukcí lze prìimout tezi, že pokud někdo svým jednáním poškodí zájmy obce, měl by za takové jednání nést odpovědnost, at' už civilněprávní, správněprávní, či trestněprávní. Problematickými

\footnotetext{
* Mgr. Petr Zarivnij, doktorand, Katedra trestního práva, Právnická fakulta Masarykovy univerzity, Brno / Ph.D. student, Department of Criminal Law, Faculty of Law, Masaryk University, Brno, Czech Republic / E-mail: 210827@mail.muni.cz
} 
se však jeví (proklamované) tendence kriminalizovat rozhodování členů samosprávných orgánů i v př́ipadech, kdy rozhodují o věcech samosprávných s dostatečnou znalostí věci, a to s přihlédnutím k zákonným ustanovením, kdy územně samosprávným celkům má být garantováno, že stát nebude až na výjimečné případy zasahovat do jejich činnosti (srov. článek 8 a článek 101 odst. 4 Ústavy České republiky).

Nejen z výše uvedených důvodů je problematika právní (trestnî) odpovědnosti osob činných ve volených orgánech územních samosprávných celků námětem k zamyšlení jak pro odborníky z oblasti správního a trestního práva, tak zejména pro samotné zastupitele, jichž se tato otázka bytostně dotýká. S ohledem na vyvstávající nejasnosti a kritiku (at’ již opodstatněnou či nikoli) ze strany odborné i laické veřejnosti Nejvyšší státní zastupitelství publikovalo k předmětné oblasti analýzu1, která si kladla za cíl shrnout a definovat limity trestní odpovědnosti osob činných ve volených orgánech územních samosprávných celků. De facto jako reakci na tuto analýzu vydala svůj materiál rovněž Unie obhájců Č ${ }^{2}$, v jehož úvodu bylo upozorněno na prohlášení Nejvyššího státního zástupce, že ,počet stíhaných volených zástupcư samospráv tvorr naprosto zanedbatelný podil zjejich celkovébo počtu", a to s dodatkem, že předmětnou problematiku nelze bagatelizovat pouhým srovnáním počtu všech zastupitelů s počty těch, kteří byli stúháni, a konstatovat, že vše je v pořádku. ${ }^{3}$ Poznatky a závěry zmíněné ve výše uvedených dokumentech jsou poté průběžně reflektovány $\mathrm{v}$ tomto článku. Nadto lze podotknout, že v České republice v současné chvíli neexistuje žádný orgán, který by se systematicky věnoval problematice trestní odpovědnosti osob činných ve volených orgánech územních samosprávných celků.

Článek se přitom nebude zabývat otázkou obecné kriminality, které se může svým způsobem dopustit každý, tedy samozřejmě i osoby činné ve volených orgánech územních samosprávných celků, nýbrž trestnými činy spáchanými při výkonu funkce, anebo v souvislosti s výkonem funkce těchto osob. V převážné míre poté budou reflektovány otázky spojené s hospodařením obce (nakládání s obecním majetkem), byt' potenciálně se oso-

1 Analýza Nejvyššriho státního zastupitelstvi: Trestni odpovédnost osob činných ve volených orgánech územních samosprávných celkủ [online]. 7 NZN 603/2014 [cit. 13. 3. 2016], 37 s. Dostupné z: http://www.nsz.cz/images/stories/ PDF/Soubory_ke_stazeni/Trestni_odpovednost_zastupitelu_analyza.pdf. Již dříve bylo Nejvyšším státním zastupitelstvím k obdobné problematice vydáno výkladové stanovisko - viz Výkladové stanovisko k postaveni pracovníku verejnoprávních instituci jako verejných činitelù č. 8/2001 [online]. 14. 6. 2001 [cit. 13. 3. 2016], 47 s. Dostupné z: http://www.nsz.cz/images/stories/PDF/Stanoviska_hmot/2001/8_2001.pdf

2 Stanovisko Unie obbájci Čr č. 3/2015 k trestnimu stíbání zastupitelù mèst a obcí [online]. 18. 3. 2015 [cit. 13. 3. 2016], 18 s. Dostupné z: http://www.uocr.cz/wp-content/uploads/2015/04/Stanovisko-Unie-obh $\%$ C3\%A1jc\%C5\%AF-\%C4\%8CR-\%C4\%8D-32015-k-trestn $\%$ C3\%ADmu-st $\%$ C3 $\%$ ADh\%C3\%A1n\%C3\%AD-zastupitel $\%$ C5\%AF-m\%C4\%9Bst-a-obc\%C3\%AD.pdf. Dále pak Př́loha c. 1 ke Stanovisku Unie obhájcu ČR $\check{c} .3 / 2015$ [online]. [cit. 13. 3. 2016], 19 s. Dostupné z: http://www. uocr.cz/wp-content/uploads/2015/04/P\%C5\%99\%C3\%ADloha-\%C4\%8D.-1-Stanovisko-Unie-obh\%C3\%A1jc \%C5\%AF-\%C4\%8CR-\%C4\%8D.-32015.pdf

3 Viz Stanovisko Unie obhájcù CrR č.3/2015, s. 1. 
by činné ve volených orgánech územních samosprávných celků při výkonu své funkce mohou dopouštět i jiné trestně postižitelné činnosti, jak bude uvedeno dále.

\section{Vymezení osob činných ve volených orgánech územních samosprávných celků a jejich postavení z pohledu trestního práva}

Druhy a postavení orgánů územních samosprávných celků jsou vymezeny (krom dílčích ustanovení Ústavy České republiky a Listiny základních práv a svobod) zejména ustanoveními \5 zákona o obcích ${ }^{4}$ \ 1 zákona o krajích ${ }^{5}$ a \ 1 zákona o hlavním městě Praze ${ }^{6}$. Povinnosti zastupitelů dále konkretizují vyhlášky a nařízení platné v obci, statuty obcí, anebo např. usnesení zastupitelstev a rad obcí. Na tomto místě je však nezbytné zdůraznit, že ne všechny orgány územních samosprávných celků jsou zároveň i volené orgány územních samosprávných celků. Tento článek se tedy zabývá trestnou činností, jež je vázána na osoby činné ve volených orgánech územních samosprávných celků, proti nimž je možné vést trestní řízení, přičemž se jedná o zastupitele ${ }^{7}, \operatorname{radní}^{8}$ a starosty ${ }^{9}$ (uvedené osoby jsou dále v textu označovány souhrnně jako ,zastupiteléc).

Rovněž je nezbytné připomenout, že oproti např. poslancům a senátorům (potažmo soudcům) nejsou zastupitelé ze zákona nadáni pro výkon své funkce imunitou, a jako takoví jsou odpovědní jak za učiněné projevy, tak i za hlasování. Pro trestní stíhání zastupitelů se ani nevyžaduje souhlas př́íslušného orgánu.

Jak již bylo naznačeno, úvahy v tomto článku směřují k souvislostem stran trestní odpovědnosti zastupitelů, jež je spojena s hospodařením obce a nakládáním s obecním majetkem. Do této kategorie spadají především skutkové podstaty trestných činů zneužití pravomoci úřední osoby ( $\int 329$ tr. zákoníku行) ${ }^{11}$ a porušení povinnosti při správě cizího majetku ( $\int 220$ tr. zákoníku), případně by se dalo uvažovat o skutkové podstatě trestného činu porušení předpisů o pravidlech hospodářské soutěže ${ }^{12}$ (『248 tr. zákoníku) či maření úkolu úřední osoby z nedbalosti ( 330 tr. zákoníku). Pro úplnost lze však dodat, že zastupitelé mohou svými projevy či hlasováním naplnit i další skutkové podstaty trestných činů, prričemž do úvahy přichází např. pomluva (184 tr. zákoníku), podněcování k trestnému činu (『 364 tr. zákoníku), schvalování trestného činu (『 365 tr.

\footnotetext{
4 Zákon č. 128/2000 Sb., o obcích (obecní zř́izenî).

5 Zákon č. 129/2000 Sb., o krajích (krajské zřízenî).

6 Zákon č. 131/2000 Sb., o hlavním městě Praze.

7 Zastupitelé obce, města, městské části, kraje, hlavního města Prahy, jakož i městyse či statutárního města.

8 Radní obce, města, městské části, kraje, hlavního města Prahy, jakož i městyse či statutárního města.

9 Rovněž i místostarosty, primátory a jejich náměstky, hejtmany a jejich náměstky.

10 Zákon č. 40/2009 Sb., trestní zákoník.

11 Resp. trestný čin zneužívání pravomoci veřejného činitele podle \158 trestního zákona č. 140/1961 Sb.

12 Zejména pokud jde o chybný výběr způsobu realizace veřejných zakázek.
} 
zákoníku), založení, podpora a propagace hnutí směřujícího k potlačení práv a svobod člověka ( 403 tr. zákoníku), projev sympatií k hnutí směřujícímu k potlačení práv a svobod člověka ( 404 tr. zákoníku) apod.

Dále lze poukázat, že v předmětné oblasti se mohou vyskytovat trestné činy jak s obecným subjektem (např. trestný čin zpronevěry podle \206 tr. zákoníku či podvodu podle \ 209 tr. zákoníku), tak i se subjektem speciálním ${ }^{13}$. V těchto př́padech dotyční vystupujî jako úřední osoby [resp. veřejní činitelé podle \89 odst. 9 trestního zákona ${ }^{14}$ (dále jen tr. zák.)] a konkrétně se tedy bude jednat právě o trestný čin zneužití pravomoci úřední osoby ( 329 tr. zákoníku). Jak ovšem podotýká např. Žd’árský, samotný fakt, že je osoba nadána určitou pravomocí, ještě neznamená, že ji také bude v konkrétním případě používat. Tudíž nemusí být dána souvislost s pravomocí a odpovědností takové úrední osoby. Předpokladem trestní odpovědnosti za trestný čin zneužití pravomoci úřední osoby podle \329 odst. 1 tr. zákoníku je tedy zjištění, zda úřední osoba v rozhodné době skutečně vykonávala svou pravomoc a zároveň jednala $v$ některé formě předpokládané v \329 odst. 1 pod písmeny a) až c) tr. zákoníku. ${ }^{15,16}$

Podle ustanovení \ 127 odst. 1 písm. d) tr. zákoníku jsou za úřední osoby považováni rovněž členové zastupitelstva územní samosprávy. Tímto postavením disponují, pokud plní úkoly státu nebo společnosti a používají přitom svěřené pravomoci pro plnění těchto úkolů. $\mathrm{K}$ trestní odpovědnosti se zároveň vyžaduje, aby byl trestný čin spáchán v souvislosti s jejich pravomocemi a odpovědnostmi (\$ 127 odst. 2 tr. zákoníku). ${ }^{17}$ Zvýšený rozsah trestní odpovědnosti úředních osob je na druhé straně vyvažován zvýšenou mírou jejich ochrany (rovněž \127 odst. 2 tr. zákoníku) v souvislosti s výkonem jejich funkce (srov. např. trestný čin násilí proti úřední osobě podle $\int 325$ tr. zákoníku).

Otázkou trestního postihu zastupitelů se již dříve zabýval Ústavní soud, který se v jednom ze svých usnesení ${ }^{18}$ vyjadřoval k otázce nemožnosti brojit tzv. komunální stížností u Ústavního soudu proti zahájení trestního stíhání zastupitelů obce. Ve svém rozhodnutí mj. uvedl, že trestni stíháni bývalých či současných zastupitelì města, členù jeho rady nebo dokonce starosty v souvislosti s hlasovánim zastupitelstva o nakládáni s majetkem mèsta mưže mit neprìmý vliv na budouci výkon samosprávy a zpuisob nakládáni s majetkem mèsta. To však nestači, aby tento orgán

13 Více $\mathrm{k}$ tomu viz např. ŽĎÁRSKÝ, Zbyněk. Trestní odpovědnost úřední osoby - téma vskutku aktuální. Státni zastupitelství. 2013, roč. XI, č. 5, s. 39.

14 Zákon č. 140/1961 Sb., trestní zákon.

15 ŽĎÁRSKÝ, Zbyněk. Trestní odpovědnost úřední osoby - téma vskutku aktuální. Státní zastupitelství. 2013, roč. XI, č. 5, s. 40.

16 Viz rovněž RIZMAN, Stanislav. \329 - Zneužití pravomoci úřední osoby. In: ŠÁMAL, Pavel a kol. Trestní zákoník II. \140 aそ̌ 421. Komentár. 2. vyd. Praha: C. H. Beck, 2012, s. 3148. ISBN 978-80-7400-428-5.

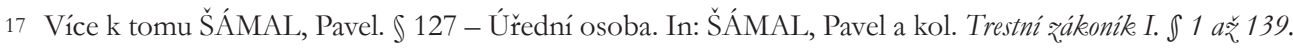
Komentár. 2. vyd. Praha: C. H. Beck, 2012, s. 1364. ISBN 978-80-7400-428-5.

18 Rozhodnutí Ústavního soudu ze dne 6. 6. 2007, sp. zn. II. ÚS 265/07. Obdobně též rozhodnutí Ústavního soudu ze dne 26. 6. 2008, sp. zn. II. ÚS 653/07. 
samosprávy byl vedle fyzickeých osob - svých současných či bývalých členů - nebo dokonce na jejich mistě oprávnèn domáhat se zrušeni roz̧hodnuti v jejich trestnich věcech, zejména maji-li tyto osoby lepši a prímèjsí cestu ke dosaženi tohoto cíle a k uplatnèni nastolené argumentace. Ústavní soud tímto postojem de facto akceptoval trestní stíhání zastupitelů, když neshledal žádné důvody, které by tomuto bránily. Obdobně Nejvyšší soud v jednom ze svých rozhodnutí19 dospěl k závěru, že vedení trestních řízení se zastupiteli nezasahuje do práva na samosprávu obcí, která je jinak zajištěna jak Ústavou ČR, tak i Evropskou chartou místní samosprávy.

\subsection{Konkrétní př́pady trestné činnosti v předmětné oblasti}

Na tomto místě lze pro ilustraci uvést některé formy trestné činnosti zastupitelů. ${ }^{20}$ Trestní odpovědnost byla v uvedených př́padech převážně dovozována z obcházení právních předpisů, kdy (zejména) starostové činili dispozice s obecním majetkem bez předcházejícího rozhodnutí zastupitelstva nebo rady.

a) Starostka na základě fiktivních dokladů, které dokládala, neoprávněně čerpala finanční prostředky obce a obchodní společnosti ve vlastnictví obce, a tyto prostředky užívala pro vlastní potřebu [ $\int 158$ odst. 1 písm. a), odst. 2 písm. c) tr. zák. a \ 248 odst. 1 , odst. 3 písm. c) tr. zák.; viz usnesení Nejvyššího soudu ze dne 16. 7. 2008, sp. zn. 7 Tdo 878/2008].

b) Starosta zfalšoval usnesení zastupitelstva a poté bez jeho vědomí uzavřel s obchodní společností tři smlouvy o půjčce a závazek obce zajistil zrrízením zástavního práva na obecních nemovitostech, přičemž peníze z pưjček použil pro svoji potřebu [ $\int 158$ odst. 1 písm. b), odst. 2 písm. c) tr. zák.; viz usnesení Nejvyššího soudu ze dne 15. 4. 2009, sp. zn. 7 Tdo 336/2009].

c) Starosta bez souhlasu zastupitelstva učinil prohlášení o ručitelství majetkem obce za závazky fotbalového klubu [〕 158 odst. 1 písm. b), odst. 2 písm. a), c) tr. zák.; viz usnesení Nejvyššího soudu ze dne 29. 4. 2009, sp. zn. 8 Tdo 1654/2008].

d) Starosta bez souhlasu zastupitelstva a bez územního rozhodnutí a stavebního povolení nechal zbudovat asfaltovou komunikaci a kanalizační př́pojky, na což použil finanční prostředky státní podpory zbylé z jiného projektu [ $\int 158$ odst. 1 písm. a) tr. zák. a \250 b odst. 2, odst. 3 tr. zák.; viz usnesení Nejvyššího soudu ze dne 24. 6. 2009, sp. zn. 6 Tdo 614/2009].

e) Starosta vědomě podepsal kupní smlouvu na prodej nemovitosti obce za nižší částku, než bylo schváleno zastupitelstvem [〕 158 odst. 1 písm. b) tr. zák.; viz usnesení Nejvyššího soudu ze dne 29. 6. 2009, sp. zn. 4 Tdo 576/2009].

f) Starosta městské části pronajal nemovitosti města bez souhlasu rady města za cenu nepřiměřeně nízkou, včetně souhlasu s odstraněním a umístěním staveb [ 158 odst. 1 písm. a), b), c) tr. zák.; viz usnesení Nejvyššího soudu ze dne 24. 2. 2012, sp. zn. 11 Tdo 454/2011].

19 Rozhodnutí Nejvyššího soudu ze dne 26. 11. 2009, sp. zn. 4 Tdo 1205/2009.

20 Viz Analýza Nejuyššíno státníbo zastupitelstuí, 7 NZN 603/2014, s. 7-22. 
g) Starosta bez vědomí zastupitelstva sjednal stavební práce a vystavil směnku na zaplacení díla, pokusil se spáchat dotační podvod a bez vědomí zastupitelstva prodal obecní rybník (158 odst. 1 písm. b), odst. 2 písm. a), b), c) tr. zák., \ 250 odst. 1, odst. 3 písm. b) tr. zák.; viz usnesení Nejvyššího soudu ze dne 20. 2. 2013, sp. zn. 5 Tdo 1452/2012].

K výše uvedeným příkladům je však potřeba doplnit, že zneužití pravomoci úřední osoby ze strany starosty není jedinou formou trestné činnosti, která se v předmětné oblasti vyskytuje. $\mathrm{V}$ hojné míre jsou zastoupeny rovněž př́ipady s úplatkářským charakterem. ${ }^{21}$ $V$ těchto případech se však zpravidla nejedná o odpovědnost většího počtu zastupitelů, nýbrž spíše o jednotlivce zastávajícího funkci starosty či místostarosty.

\section{$3 \quad \mathrm{~K}$ trestnímu postihu zastupitelů a rozhodovací praxi Nejvyššího soudu ČR}

Již byl zmíněn postoj Ústavního soudu (viz usnesení Ústavního soudu ze dne 6. 6. 2007, sp. zn. II. ÚS 265/07) k trestnímu stíhání zastupitelů, byt’ takové stíhání může mít (nepřímý) vliv na budoucí výkon samosprávy a nakládání s majetkem města. Případnou trestní odpovědností zastupitelů se poté v rámci rozhodovací činnosti častěji zabýval Nejvyšší soud. V následující části článku bude upozorněno na několik rozhodnutí, která svým způsobem mohou formovat postoje orgánů činných v trestním řízení k potenciálnímu stíhání zastupitelů.

Za svým způsobem průlomové (nejen pro potřeby policie a státních zastupitelstvî) lze označit rozhodnutí Nejvyššího soudu ${ }^{22}$, ve kterém byla aprobována trestní odpovědnost každého jednotlivého zastupitele za zpo̊sob, jakým (jako člen zastupitelstva) hlasuje, př́ičemž Nejvyšší soud zdůraznil, že se nejedná o kolektivní odpovědnost.

Ve stručnosti lze k tomuto př́ípadu připomenout, že zastupitelstvo města Liberec rozhodovalo o převodu nemovitostí z majetku obce na manželský pár, a to za cenu 1,5 milionu Kč (k této částce dospěl jeden z odborů magistrátu města). Část zastupitelů však namítala, že dle jejich informací (podložených odhady realitních makléřů) je cena pozemků alespoň 5 milionů Kč. V tomto př́slušné státní zastupitelství spatřovalo vznik škody 3,5 milionu Kč. Okresní soud nejprve trestní stíhání zastavil a následnou stížnost soud druhého stupně zamítl jako nedůvodnou. V reakci na dovolání Nejvyššího státního zastupitelství však Nejvyšší soud mj. předestřel, že:

„Zavinèni z védomé, resp. hrubé nedbalosti (\$ 5 písm. a) tr. zák., \16 odst. 1 pism. a), odst. 2 tr. zákoniku] by zde bylo možné dovodit u členu zastupitelstva obce mimo jiné z toho, že na zasedáni za-

21 Srov. např. rozhodnutí Nejvyššího soudu ze dne 31. 5. 2012, sp. zn. 8 Tdo 1131/2011; rozhodnutí Nejvyššího soudu ze dne 12. 6. 2013, sp. zn. 3 Tdo 396/2013; anebo rozhodnutí Nejvyššího soudu ze dne 25. 6. 2013, sp. zn. 7 Tdo 552/2013.

22 Srov. rozhodnutí Nejvyššího soudu ze dne 19. 12. 2012, sp. zn. 5 Tdo 827/2012. 
stupitelstva obce, na nèmž se roz̧hodovalo o schváleni prodeje nemovitého majetku obce, byli upozornèni jinými členy zastupitelstva obce na určité skutečnosti, z. nichž vyplývá možnost príliš nižké kupní ceny a keteré védomě pominuli.

Trestni odpovédnosti každébo z členu zastupitelstva obce, který blasoval pro schválení nevýhodnébo prodeje nemovitébo majetku obce, pak nebráni ani skutečnost, jestliže roz̧hodoval jako člen kolektivního orgánu obce. Ke schváleni prodeje nemovitého majetku obce se totiž vyžaduje soublas nadpolovični vétšiny

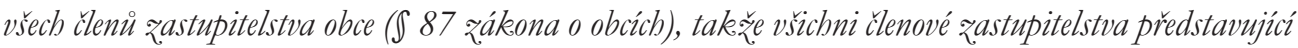
tuto vétšinu, bylo-li jí dosaženo, se bezprostrédně podíleli na prujjetí takovébo rozhodnutí zastupitelstva obce, pričemž každý z nich mèl stejný blas. Proto i trestni odpovědnost za schváleni a dìsledky rozhodnuti prijatého żminènou vétšinou, pokud bylo učinèno v rozporu s povinností členù zastupitelstva obce rádnè spravovat majetek obce (』38 a násl. qákona o obcích), mohou nést všichni členové qastupitelstva obce, kterri hlasovali pro schváleni určitého rozhodnutí, jímž byla zpisobena škoda na majetku obce."

Z výše uvedeného rozhodnutí tedy lze dovodit, že trestní odpovědnost za schválení rozhodnutí (s nastalými důsledky), které bylo přijato většinou zastupitelů, a pokud tedy bylo učiněno $\mathrm{v}$ rozporu s povinností zastupitelů řádně spravovat majetek obce, mohou nést všichni členové zastupitelstva, kteří hlasovali pro přijetí určitého rozhodnutí, kterým byla způsobena škoda na majetku obce.

Analýza Nejvyššího státního zastupitelství poté definovala nejčastější skutečnosti, jež vedly k zavinění z vědomé (či hrubé) nedbalosti členů zastupitelstva: ${ }^{23}$

- členové byli př́tomni na zasedání zastupitelstva rozhodného dne;

- předmětem jednání bylo rozhodování o prodeji nemovitého majetku obce;

- přítomní členové byli upozorněni na skutečnosti, ze kterých vyplývá, že cena, za kterou se navrhuje nemovitost prodat, může být př́liš nízká;

- členové takové upozornění pominuli;

- členové přes uvedené upozornění hlasovali pro schválení (nevýhodného) prodeje nemovitého majetku obce;

- usnesení o schválení nevýhodného prodeje nemovitého majetku obce bylo přjato nadpoloviční většinou všech členů zastupitelstva obce, tudíž uvedená většina členů zastupitelstva se bezprostředně podílela na přijetí předmětného rozhodnutí, přičemž každý z jeho členů měl stejný hlas.

Zároveň však nesmí být opomenuto, že v českém právu platí princip individuální trestní odpovědnosti, tudíž je nezbytné zjišt'ovat individuální trestní odpovědnost každého zastupitele zvlášt'. Zcela neprrijatelné by bylo učinit závěr, že odpovědné je celé zastupitelstvo, a to bez znalosti toho, kdo jakým způsobem hlasoval. I po prrijetí zákona o trestní odpovědnosti právnických osob ${ }^{24}$ české trestní právo hmotné nezná kolektivní odpovědnost většího počtu fyzických osob, ale vždy je třeba zvažovat jednání konkrétních

23 Viz Analýza Nejvyššího státního zastupitelství, 7 NZN 603/2014, s. 27.

24 Zákon č. 418/2011 Sb., o trestní odpovědnosti právnických osob a řízení proti nim. 
fyzických osob v návaznosti na přičitatelnost jednání právnické osobě. Zákon o trestnî odpovědnosti právnických osob nadto ve svém \6 odst. 1 písm. b) výslovně vylučuje dopad tohoto zákona na územní samosprávné celky (stran výkonu veřejné moci).

Některými spornými (do té doby ne zcela vyjasněnými) body se dále Nejvyšší soud zabýval např. v rozhodnutí ${ }^{25}$ týkajícím se pohnutky u trestného činu zneužití pravomoci úřední osoby, přičemž mj. dospěl k závěru, že ,jestliže pachatel v postaveni úredni osoby nejednal se znalostí rozhodných skutećností, nelze zpravidla učnit ani závèr o jeho úmyslu zpuisobit jinému škodu nebo jinou závažnou újmu ve smyslu \329 odst. 1 tr. zákoníku“, přičemž ,úmyslné zavinění pachatele za prěrin porušení povinnosti pri správě ciąiho majetku podle $\int 220$ odst. 1 tr. zákoniku lze dovodit též z. toho, že jako starosta obce zámèrnè nerespektoval pravomoc zastupitelstva nebo rady obce".

$\mathrm{V}$ jiném rozhodnutíi ${ }^{26}$ zabývajícím se zaviněním starosty obce však Nejvyšší soud předestřel, že „u výkonu funkece starosty se predpokeládá znalost zákona č. 128/2000 Sb., o obcich (obecni žriżeni), ve znèni pozdèjšich prèdpisü, a v prípadě starosty mèstské části i żnalost statutu územnè clenèného statutárního mèsta. Jestliže tedy starosta za obec či př̀islušnou mèstskou část podepisuje smluvní dokumenty, musi si být védom i prípadnébo rozporu v obsabu smluv se statutem a obecně qávaznými právnimi predpisy".

Nadto Nejvyšší soud konstatoval, že ,jestliže se laické osoby spolehnou na rady advokáta jako osoby práva znalé, aniž by zde byly néjaké konkrétni okolnosti, ze keterých by mobly usuzovat na nesprávnost takových rad, nelze u nich zpravidla dovodit úmyslné zavinèn “227.

Krom výše uvedeného lze poukázat na další rozhodnutí Nejvyššího soudu ${ }^{28}$, ve kterém se jednalo o odkup 100\% akcií Pivovaru Náchod. Na jedné straně stála obchodní společnost L., a. s., která nabízela částku 150 milionů Kč, přičemž tato měla být uhrazena ihned po uzavření smlouvy, na druhé pak společnost Pivovar H., a. s., která sice nabízela částku o 35 milionů Kč vyšší, avšak s ohledem na navrhované smluvní podmínky nebylo zcela jisté, že částka v této výši bude opravdu uhrazena. Nejvyšší soud přitom dospěl k závěru, že „prèstože cena stanovená společností Pivovar H., a. s., byla o 35 milionů vyšš̌, na čemž dogmaticky dovolatel (Nejvy šsí státni zastupitelstui) stavi své tvrzueni o vaniku škody ve formè majetkové újmy, ve skutečnosti se jeji úhrada jevila nejistou, a to nejen ve svém rozsabu, ale dokonce budouci možná neshoda stran na jejím snízeni mohla pro kupujicího znamenat právo odstoupeni od smlouvy. Proto je nutné odmitnout názor nejvy ššiho státního zástupce o poškožni mèsta N. výbèrem kupujicího, který byl ochoten, (a také tak následně fakticky učnil), zaplatit za akcie cenu sice nižšri, ale bezprostredně po uzavreni smlouvy ber jakýchkoli podminek. Nabidka společnosti Pivovar H., a. s., byla pro prodávajicího natolik riskantni v možných disledcich, a to s obledem na dobu splatnosti, ale predevǐim

\footnotetext{
25 Srov. rozhodnutí Nejvyššího soudu ze dne 26. 2. 2014, sp. zn. 5 Tdo 77/2014.

26 Srov. rozhodnutí Nejvyššího soudu ze dne 24. 2. 2012, sp. zn. 11 Tdo 454/2011.

27 Srov. rozhodnutí Nejvyššího soudu ze dne19. 1. 2011, sp. zn. 5 Tdo 848/2010.

28 Srov. rozhodnutí Nejvyššího soudu ze dne 16. 7. 2014, sp. zn. 5 Tdo 273/2014.
} 
na naprosto neprèdvidatelný a pro mèsto $N$. dokonce neovlivnitelný vývoj (fakticky nesmèlo vykonávat akcionárská práva), že rozumnè uvažujici osoba by na ni nepristoupila. Z tohoto pobledu neni mo:̌né vyčitat výbèrové komisi a členưm obou orgánu mèsta i obvinènému, že prù výbèru vhodného smluvního partnera na odkoupeni akecii Pivovaru N., a. s., považovali za pro mèsto výhodnèjsí a lepšsi nabidku obchodni společnosti L., a. s.“.

V souvislosti s uvedenými př́pady je namístě podotknout, že právě otázka způsobené škody bývá značně problematická. $V$ př́padě náchodského pivovaru státní zastupitelství stavělo obžalobu na vzniku škody 35 milionů Kč. V př́ípadě prodeje nemovitostí libereckým zastupitelstvem poté měla vzniknout škoda ve výši 3,5 milionů Kč. Přesto, výše škody by měla být bezpečně zjistitelná a ověřitelná. Konstrukce, že by se našel zájemce (v libereckém prrípadě), který by předmětné pozemky koupil za cenu 5 milionů Kč, je čistě hypotetická.

K této problematice lze upozornit na materiál Ministerstva vnitra, který se mj. věnoval odchylce od obvyklé ceny. ${ }^{29}$ Dle metodického doporučení Ministerstva zákon požaduje, aby odchylka od obvyklé ceny byla zdůvodněná. Tato povinnost v sobě zahrnuje dva aspekty - odchylka musí být odůvodnitelná, tedy musí být založena na legitimních, objektivních důvodech, a zároveň tyto důvody musí být prokazatelným způsobem zaznamenány. Důvod pro odchylku předně musí objektivně obstát při posuzování, zda určitá dispozice byla skutečně účelná a rozumná (může jím být nap̌r. vybudování prodejny potravin nebo pomoc občanům v nouzi, avšak důvodem patrně nebude pouze špatný technický stav nemovitosti, jenž se odrazí již ve výši „obvykléc ceny). Tudíž je potřeba zdůvodnit takovou odchylku, při které je cena nižší než cena obvyklá (při úplatném převodu majetku). Lze poznamenat, že u ceny vyšší je zdůvodnění odchylky již implicitně obsaženo v evidentní ekonomické výhodnosti dispozice pro obec, a není proto treba takovou odchylku zvlášt' výslovně odůvodňovat. Důvody pro odchylku přitom budou obecně dány bud' tehdy, jestliže prodej majetku za cenu obvyklou v konkrétním případě není možný, anebo pokud s ohledem na povinnost obce pečovat o všestranný rozvoj (a potreby svých občanů) a s ohledem na její povinnost pečovat o rozvoj a zachování obecního majetku nebude obec převodem za nižší cenu poškozena, tedy pokud prodej za nižší než obvyklou cenu přinese obci jiné výhody. $\mathrm{K}$ tomu předmětný materiál Ministerstva dále uvádí, že s ohledem na shora uvedené je třeba přihlížet nejen k aktuálnímu ekonomickému profitu, který z dané operace územní samosprávný celek má, nýbrž s ohledem na nutnou kontinuitu jejich hospodaření je nezbytné přihlížet rovněž k tomu, jaké důsledky bude mít dané jednání do budoucna, pokud je právě ekonomický profit zamýšleným cílem daného jednání, přičemž v tomto ohledu nesmí jít o nějaké neurčité či hypotetické výhody či zisky, ale o legitimně očekávanou výhodnost celého jednání.

29 Podle Metodickébo doporučeni ke rimnosti územnich samosprávných celkè č. 7: povinnosti obci pru nakládáni s obecnim majetkem podle zákona o obcích [online]. [cit. 14. 3. 2016], s. 22-23. Dostupné z: http://www.mvcr.cz/odk2/ soubor/metodicke-doporueni-blue-07-1-web-v2-pdf.aspx 
Z výše uvedených rozhodnutí Nejvyššího soudu je patrné, že jakékoli námitky stran jednotné linie, která by snad měla být nastavena pouze v duchu trestní represe a nápomoci policejním orgánům a státním zastupitelstvím, jsou zcela neopodstatněné. Nejvyšší soud předkládanou judikaturou pouze vymezuje pomyslné mantinely, $\mathrm{v}$ rámci nichž lze uplatnit trestní represi vůči osobám činným ve volených orgánech územních samosprávných celků.

Nad rámec uvedeného lze podotknout, že v letech 1995 až 2014 bylo vedeno celkem 75 trestních řízení proti celkem 266 zastupitelům. Z těchto bylo k únoru 2015 pravomocně skončeno 43 (trestních řízenî) proti 100 zastupitelům. Z počtu 43 pravomocně ukončených trestních řízení bylo 19 ukončeno výrokem o vině obviněného zastupitele, 17 ukončeno zproštěním obžaloby soudem, 5 ukončeno státním zástupcem, zbylé byly zastaveny či došlo ke zrušení usnesení o zahájení trestního stíhání. ${ }^{30}$

\section{Výhrady zastupitelů}

Na tomto místě lze dále poukázat na nejčastější obavy a výhrady zastupitelů stran jejich rozhodovací činnosti a potenciálního trestního stíhání. Mezi tyto výhrady obvykle patří: ${ }^{31}$

- Složitost právni úpravy a na ni navazujici trestni postih pro porušeni zákona, stejnè jako prehliženi zásady ultima ratio. $\mathrm{V}$ tomto je upozorňováno zejména na oblast zadávání veřejných zakázek, kdy právní řád České republiky podléhá častým změnám. Přitom jakékoli pochybení (dle dotazovaných zastupitelů) ihned slouží jako podklad pro zahájení trestního řízení. Krom toho, trestní postih by měl nastupovat až poté, co byly vyčerpány jiné formy a prostředky práva - tedy instituty civilního a správního práva.

- Narušeni právni jistoty zastupitelì, že nemohou být trestně stíháni, pokud budou o záležitostech obce rozhodovat podle svého nejlepšího védomi a svédomí. Zastupitelé v této souvislosti poukazují na prvek právní jistoty, jakožto jeden ze základních znaků právního státu.

- Postupné presouváni rozhodovacich pravomocí ze zastupitelu na advokáty, znalce č jüné poradce. Zastupitelé se tímto postupem snaží bránit rizikům, že budou vystaveni trestnímu postihu. Souběžně však výrazně rostou náklady na obstarávání posudků, vyjádření, odborných stanovisek, analýz apod. Vynaložené finanční prostředky by přitom obce mohly investovat mnohem efektivněji, např̀ v rámci rozvoje infrastruktury.

- Rozhodováni clenu zastupitelstva v krajni nouzi, avšak následnè jsou nesprávnè vyhodnoceny okolnosti vylučujicí odpovédnost. V těchto případech se vyskytují rozhodnutí, která musí zastupitelé přijmout, aby např. zabránili hrozícím škodám. Přesto jim za taková rozhodnutí hrozí trestní postih.

- Panujicí nesoulad mezi názory odborné i laické veréjnosti a názory orgánu činných v trestním rízeni stran posouzeni trestnosti jednání. V tomto bývá namítáno, že orgány činné v trestním

\footnotetext{
30 Podle Stanoviska Unie obhájcu Cr č č.3/2015, s. 13.

31 Srov. Stanovisko Unie obhájci ČR č. 3/2015, s. 7 a násl.
} 
řízení dokáží být velmi inovativní, zejména co se týče právních konstrukcí, na nichž je stíhání zastupitelů založeno.

- Výskyt situací, které musi být zastupitelstvem réšeny a rozhodnuty, avšak nelze je vyřšrit bez rizika trestního postihu. Zastupitelé v tomto namítají, že riziko trestního postihu existuje jak při hlasování pro navržené usnesení, tak i v př́padě, že budou hlasovat proti jeho prijetí.

- Rostouci ingerence orgánů činných v trestním rǐzeni do výkonu samostatné puisobnosti obci a mèst. $\mathrm{K}$ tomuto lze připomenout případ, kdy bylo rozhodnuto o naložení s majetkem obce za cenu dle znaleckého posudku, avšak odpovědné osoby byly trestně stíhány ( $\int 158$ tr. zák.), jelikož znalec jmenovaný policií dospěl k odlišné ceně. Až odvolacím soudem došlo ke zrušení původního rozsudku a zproštění obžaloby, přičemž následně Nejvyšší soud zamítl dovolání nejvyššího státního zástupce. ${ }^{32}$ Nabízí se tedy otázka, kolik by si vždy mělo zastupitelstvo nechat pro svoji rozhodovací činnost vypracovat posudků, aby nehrozila ingerence orgánů činných v trestním řízení.

- Rovněž se objevují názory, že přísnost, s níž postupují orgány policie a státní zastupitelství při posuzování jednání členů zastupitelstva, již není úměrná té, jež by měla být aplikována právě u policie a státních zástupců v situacích, kdy dojde k zastavení předmětného řízení či zproštění obžaloby, čímž bude de facto vyslovena nesprávnost jejich postupu.

S ohledem na výše uvedené lze shrnout, že jistá nepředvídatelnost postupu orgánů činných $\mathrm{v}$ trestním řízení vůči zastupitelům vyvolává obavy z ,jakéhokoli“ rozhodování, případně z potenciálního několikaletého (bezdůvodného) trestního stíhání. Takové obavy mohou vést k paralýze činnosti samosprávy, zvyšování nákladů spojených s rozhodovací činností obcí (odměny znalcům a advokátům za jejich rady a podklady) a potenciálně rovněž k přesouvání faktického rozhodování z těch, kteř́ byli demokraticky zvoleni, na znalce, advokáty, nejrůznější poradce apod.

\section{Doporučení a rizika}

Jak bylo zmíněno např. v Analýze Nejvyššího státního zastupitelství33, s ohledem na závěry usnesení Nejvyššího soudu ze dne 19. 12. 2013, sp. zn. 5 Tdo 827/2012, bylo možné očekávat, že ze strany kolektivních orgánů územních samosprávných celků budou činěna opatření (za účelem znemožnění identifikace konkrétních hlasujících) spočívající v tom, že hlasování budou konána jako tajná, a to s „pojistkou“, že vždy bude zajištěn alespoň jeden opačný hlas. Pokud by následně všichni členové takového orgánu odmítli v rámci trestního řízení vypovídat, nebylo by možné identifikovat konkrétní osoby, vưči nimž by měla být dovozována trestněprávní odpovědnost. Rovněž se vyskytly názory, že někteří zastupitelé úmyslně odjîžcějí na dovolenou v době hlasování, aby se touto ces-

32 Viz rozhodnutí Nejvyššího soudu ze dne 16. 7. 2014, sp. zn. 5 Tdo 273/2014.

33 Viz Analýza Nejvyšš́ho státníbo zastupitelství, 7 NZN 603/2014, s. 35. 
tou vyhnuli případnému trestnímu stíhání, zejména pak, pokud je na programu jednání zastupitelstva projednávání a schvalování kontroverzních návrhů. Obdobně by se zastupitelé mohli snažit vyloučit své (úmyslné) zavinění tím, že budou odkazovat na různá odborná vyjádření, analýzy apod. Varianty tajných hlasování by však šly zcela proti trendu větší transparentnosti ve veřejném sektoru a jeho zprůhlednění, tudíž řešení tohoto či obdobného typu by se sice mohlo některým zastupitelům „vyplatit“, avšak z dlouhodobého hlediska by se jednalo o neudržitelný postoj.

Mezi doporučení, jež by připadala v úvahu za účelem snížení rizika trestního postihu, lze řadit průběžné vzdělávání zastupitelů (především v oblasti práva), důsledné vedení zápisů z jednání orgánů územních samosprávných celků (za účelem ochrany samotných zastupitelů) či úpravu pravidel pro hospodaření s majetkem územních samosprávných celků. Např. Toman doporučuje, aby veškeré počiny zastupitelstva byly zveřejněny, jelikož v některých př́padech právě ono zveřejnění bylo soudem vyhodnoceno tak, že nebylo cílem nikoho poškodit. ${ }^{34}$

Vzdělávání zastupitelů by mohlo mít i takovou podobu, že pro dosažení konkrétní funkce by bylo nutné disponovat jistým stupněm odborné kvalifikace (nikoli ve smyslu univerzitního titulu). Následně by zastupitelé měli povinnost absolvovat pravidelná školení, doplněná o (upravený) model přezkoušení, např. s nutností dosažení potřebných bodů. Jestliže má starosta obce, který dosáhl např. vyššího odborného vzdělání technického oboru, dělat pro obec ekonoma, znalce, právníka apod., nelze se podivovat, že se dřive či později dostane do konfliktu se zákonem. Jak opět podotýká Toman, zákon nevyžaduje, aby byl každý odborníkem na úplně všechno, ale pokud něčemu nerozumí, měl by si to uvědomit a (podle okolnostî) obstarat si nap̌r. odborný posudek, resp. další podklady, pro rozhodnutí v dané věci. ${ }^{35}$ Zároveň se nejeví jako nezbytné čerpat pokaždé obecní prostředky na zaplacení služeb advokáta či znalce, když existuje možnost obrátit se mj. na patřičné orgány (nadř́izené úřady) a informovat se o metodice pro postup $\mathrm{v}$ daných prípadech.

Oproti tomu však lze uvažovat o větší míre odpovědnosti předkladatele konkrétního návrhu, jelikož právě on by měl vědět o všech souvisejících okolnostech. Trestní odpovědnost by tedy měl nést primárně předkladatel, a až následně další zastupitelé, pokud by z jejich strany byla prokázána zejména subjektivní stránka předmětného trestného činu.

Byt' za alespoň teoretickou úvahu poté stojí, zda by ve vztahu k zastupitelům neměla být přijata úprava, která by je vybavila určitou dávkou imunity (stran hlasovánî), resp. zda

34 TOMAN, Petr. Trestněprávni odpovédnost zastupiteli - II [online]. Právní prostor, publikováno 16. 12. 2015 [cit. 13. 3. 2016]. Dostupné z: http://www.pravniprostor.cz/clanky/trestni-pravo/ trestnepravni-odpovednost-zastupitelu-ii

35 TOMAN, Petr. Trestnéprávni odpovédnost zastupitelì - I [online]. Právní prostor, publikováno 15. 12. 2015 [cit. 13. 3. 2016]. Dostupné z: http://www.pravniprostor.cz/clanky/trestni-pravo/ trestnepravni-odpovednost-zastupitelu-i 
by nebylo potřeba udělení souhlasu k jejich trestnímu stíhání prŕíslušným orgánem. Zdá se však, že takové řešení není aktuální, nebot’ tendence ve společnosti se ubírají opačným směrem, kdy např. u poslanců či senátorů je spíše zvažováno omezení jejich imunity. ${ }^{36}$

Druhou rovinu poté může představovat posílení odpovědnosti státních zástupců, a to např. přenesením formálního důkazního břemene na státní zástupce, kteří by byli v jistém smyslu zatíženi negativními důsledky zprošt’ujícího rozhodnutí. Ostatně, s novým pojetím důkazního břemene státního zástupce počítá navrhovaná rekodifikace trestního práva procesního, resp. této otázce se obsáhleji věnují „,východiska a principy“ nového trestního řádu. Přitom by nemělo zůstat u pouhého prohloubení kontradiktornosti řízení před soudem, a s tímto souvisejícím posílením zásady obžalovací, nýbrž mělo by se jednat o poměrně výrazný zásah do struktury trestního procesu. Důsledné opatřování důkazů již v př́pravném řízení by mělo mít za výsledný efekt respektování požadavku, aby obžaloba byla podávána jen v důvodných př́padech, kdy tato důvodnost bude výsledky prrípravného řízení přezkoumatelná. Důsledky neunesení důkazního břemene, kdy se nepodaří vyhledat, opatřit a zajistit důkazy prokazující vinu obviněného, by tedy zatíżily primárně státního zástupce, nikoli v první řadě soud a až ex post státního zástupce. ${ }^{37}$ Přitom se však nebude jednat o taková opatření, která by státní zástupce limitovala při výkonu jejich funkce. Spíše jde o potlačení systému, ve kterém dospěje-li státní zástupce do bodu, kdy není zcela zřejmé jak v předmětné věci dál postupovat, tak podává obžalobu a další průběh již ponechá na soudu. Nap̌r. na zprošt’ující rozsudky nelze bez dalšího nazírat jako na selhání soudů, nýbrž jako na patrně nedostatečnou (bez snahy jakékoli paušalizace) práci již policejních orgánů a právě státních zástupců. Zatímco se tedy zastupitelé dostávají pod tlak, státním zástupcům de facto žádný postih za zcela bezpředmětné trestní stíhání nehrozí.

\section{Závěrem}

V soudobé demokratické společnosti odpovídají zastupitelé za spáchanou trestnou činnost jako každá jiná osoba. Nelze tedy jako primární hledisko posuzovat, jakou funkci dotyčná osoba zastává, zejména pak s absentující imunitou, nýbrž zda spáchala trestný čin či nikoli. Mandát člena zastupitelstva obce přitom vzniká zvolením a zastupitel svůj mandát vykonává osobně a v souladu se svým slibem, přičemž není vázán žádnými příkazy (〔 69 odst. 4 zákona o obcích). Pokud by tedy došlo na posuzování odpovědnosti pro způsob hlasování, tak se zastupitel nemůže dovolávat např. linie stanovené politickou stranou, od které se nemůže odchýlit (tedy nemůže se takových okolností dovolávat stran př́padné trestní odpovědnosti). Problematické poté nadále zůstává zejména pro-

36 Viz např. změna Ústavy České republiky provedená ústavním zákonem č. 98/2013 Sb.

37 Viz podrobněji dokument Východiska a principy nového trestního rádu, dostupný v rámci sekce Rekodifikace trestního práva procesního [online]. [cit. 16. 9. 2016]. Dostupné z: http://portal.justice.cz/Justice2/MS/ ms.aspx?j $=33 \& o=23 \& \mathrm{k}=4980 \& \mathrm{~d}=281460$ 
kazování subjektivní stránky (u trestného činu zneužití pravomoci úřední osoby podle \329 tr. zákoníku, resp. dřive zneužívání pravomoci veřejného činitele podle \ 158 tr. zák.) ve znaku v úmyslu způsobit jinému škodu nebo jinou závažnou újmu anebo opatřit sobě nebo jinému neoprávněný prospěch. ${ }^{38}$ Právě neprokázání subjektivní stránky vede soudy nejčastěji ke zprošt'ujícím rozhodnutím. Nadto lze opětovně podotknout, že v České republice neexistuje orgán, který by se dlouhodobě a systematicky věnoval právě problematice trestní odpovědnosti zastupitelů. Takový orgán by přitom předmětnou trestnou činnost mohl sledovat a vyhodnocovat jednotlivé př́ipady, stejně jako předkládat návrhy legislativních změn apod.

Rovněž je namístě upozornit, že ne pro všechny případy by měly být (s vidinou zbavení se případné odpovědnosti) vypracovávány znalecké posudky, analýzy apod. Pokud by si např. starosta obce nechal vypracovat posudky, jak se postavit k nálezu Ústavního soudu, který upravil regulaci hazardu v rámci místní správy, přičemž takové posudky by měly potenciál vyústit maximálně v obecné tvrzení, že nález Ústavního soudu je skutečně třeba respektovat, tak takovým jednáním by se zmíněný starosta mohl poměrně snadno vystavit trestnímu stíhání pro porušení povinnosti při správě cizího majetku.

Do rozporu s povinností postupovat s péči řádného hospodáře se často dostávají obce, které upřednostňují podporu svých vlastních občanů či přímo rozvoj obce jako takové. Je nezbytné pamatovat, že obce mají i jiné zájmy než jen řádnou správu majetku, kterými je právě péče o občany a obec jako takovou. V tomto je nezbytné mít na paměti, že nemluvíme vždy o zastupitelstvech velkých měst, nýbrž malých obcí, kde, uprímně řečeno, jsou tamní obyvatelé rádi, že se někdo z jejich řad vůbec funkce starosty a zastupitelů ujme. Problematická je poté zejména otázka přezkoumávání a hodnocení rozhodování zastupitelských sborů bez znalosti místních podmínek a specifik problému. Obcím, městům a krajům je garantována (Ústavou či Evropskou chartou místní samosprávy) určitá míra samostatnosti v rozhodovacích procesech. Přitom nelze cíle rozhodování samosprávných celků zobecňovat a posuzovat paušálně, bez pochopení (a př́padné akceptace) motivů pro konkrétní rozhodnutí. Právo na samosprávu by tak mělo být respektováno zejména ve věcech, kdy orgán samosprávy učiní rozhodnutí, a to se znalostí věci, s dostatečnými podklady, a rozhodne se tak pro určité řešení, byt’ pro obec ekonomicky méně výhodné než jiné potenciální varianty, avšak toto své rozhodnutí dostatečným způsobem vysvětlí a obhájí. ${ }^{39}$ A nelze než doporučit, aby veškeré počiny zastupitelstev (vyjma ospravedlnitelných výjimek) byly zveřejněny, resp. zpřístupněny široké veřejnosti, nebot' jak již bylo zmíněno, právě ono zveřejnění bylo soudy v některých případech vyhodnoceno tak, že nebylo cílem něco zatajit, př́ípadně někoho poškodit.

\footnotetext{
38 K subjektivní stránce viz např. RICHTER, Martin. Je možné spáchat trestný čin zneužití pravomoci úřední osoby při dispozici s majetkem územní samosprávy? Trestnéprávní revue. 2014, roč. 13, č. 5, s. 115.

39 Srov. např. rozhodnutí Nejvyššího soudu ze dne 16. 7. 2014, sp. zn. 5 Tdo 273/2014.
} 